\title{
Undergraduate Students' Difficulties in Solving Derivative and Integral Mathematical Problems
}

\author{
Nourooz Hashemi ${ }^{\mathrm{a} *}$, Mohd Salleh $\mathrm{Abu}^{\mathrm{b}}$, Hamidreza Kashefi ${ }^{\mathrm{a}}$ \\ ${ }^{a}$ Department of Mathematics Education, Farhangian University, Tehran, Iran \\ ${ }^{b}$ Department of Science, Mathematics and Creative Multimedia Education, Faculty of Education, Universiti Teknologi Malaysia, UTM Skudai, 81310, Johor, \\ Malaysia \\ *Corresponding author: h.nourooz@cfu.ac.ir
}

Article history: Received 18 October 2018 Received in revised form: 21 January 2019 Accepted: 11 April 2019 Published online: 30 April 2019

\begin{abstract}
Undergraduate students often experienced difficulty in solving problem related to derivative and integral topics. The main goal of this study was to investigate the reasons of students' difficulties in solving derivative and integral problems based on mathematical thinking approach. The participants of the study consisted of 63 undergraduate students. A test contained derivative and integral problems was given to students and the results was analyzed by quantitative and qualitative methods. Results revealed that the reasons of students' difficulties in solving problems were inability to use suitable problem solving framework, weakness in recalling previous knowledge in entry and attack steps of specialization and generalization, weakness in making connection between embodied and symbolic worlds of mathematical thinking and using symbolic world rather than embodied world.
\end{abstract}

Keywords: Derivative; integral; mathematical thinking; problem solving, undergraduate students

\begin{abstract}
Abstrak
Pelajar sarjana sering mengalami kesukaran untuk menyelesaikan masalah yang berkaitan dengan topik derivatif dan integral. Matlamat utama kajian ini adalah untuk menyiasat sebab-sebab kesukaran pelajar dalam menyelesaikan masalah derivatif dan integral berdasarkan pendekatan pemikiran matematik. Matlamat utama kajian ini adalah untuk menyiasat sebab-sebab kesukaran pelajar dalam menyelesaikan masalah derivatif dan integral berdasarkan pendekatan pemikiran matematik. Peserta kajian ini terdiri daripada 63 orang pelajar sarjana muda. Satu ujian yang mengandungi masalah derivatif dan integral diberikan kepada pelajar dan keputusan dianalisis dengan kaedah kuantitatif dan kualitatif. Keputusan menunjukkan bahawa sebab-sebab kesukaran pelajar dalam menyelesaikan masalah ialah ketidakupayaan untuk menggunakan rangka penyelesaian masalah yang sesuai, kelemahan dalam mengingat semula pengetahuan terdahulu dalam kemasukan dan menyerang. langkah pengkhususan dan generalisasi, kelemahan dalam membuat hubungan antara dunia yang diwujudkan dan simbolik pemikiran matematik, serta menggunakan simbolik dunia daripada dunia yang diwujudkan.
\end{abstract}

Kata kunci: Derivatif; integral; pemikiran matematik; penyelesaian masalah; pelajar sarjana muda

(C) 2019 Penerbit UTM Press. All rights reserved

\subsection{INTRODUCTION}

Derivatives as well as integrals are essential and prerequisite concepts of university mathematics inside the different fields (Tall, 1992, 1993, 1997, 2004a, 2011). Learning derivative along with integral are useful for students in order to discover other mathematical lessons at university levels (Tall, 2010a, 2011; Tarmizi, 2010).However, Derivatives and Integrals are among the obstacles in learning calculus as its particular concepts (Termizi, 2010; Tall, 2010a, 2012; Pepper et $a l, 2012$ ).

Derivatives and also integrals are difficult concepts of calculus for some undergraduate college students (Tall, 1993, 1997, 2011; Willcox and Bounova, 2004; Metaxas, 2007; Tarmizi, 2010; Rubio and Chacon, 2011; Pepper et al., 2012). The difficulties are due to their inadequate problem solving abilities such as lack of using suitable problem solving framework and weakness in recalling previous knowledge.

Some researchers support their students to overcome difficulties in solving the problems of derivative and integral by promoting mathematical thinking (Dubinsky, 1991; Schoenfeld, 1992; Tall, 1986, 1995, 2002a, 2002b; Watson and Mason, 1998; Tall and Yudariah, 2009; Gray and Tall, 2001; Mason, 2002; Roselainy, 2008; Mason, Burton and Stacey, 2010). Although some new methods have been invented to support students' problem solving in derivatives and integrals based on mathematical thinking, undergraduate students still have serious difficulties in problem solving of derivatives and integrals Yazdanfar (2006), Roknabadi (2007), Aghaee (2007), Parhizgar (2008), Javadi (2008), Ghanbari (2010), Ghanbari (2012), Azarang (2008; 2012) and Tavanaei (2018).

Mathematical thinking as the main component of mathematics education can play an important role to provide a suitable way of learning and teaching mathematical concepts such as derivative and integral (Tall, 2004a; Stacey, 2006; Kardage, 2008). According to Tall (2004 a; 2004 b), there are three significantly different worlds of mathematical thinking, namely: conceptual-embodied, perceptualsymbolic, and axiomatic-formal. Three worlds of mathematics can support mathematical thinking in problem solving process namely 
specialization, conjecturing and generalization (Tall, 2002; Mason et $a l, 2010$ ). The mathematical thinking process and three worlds can be useful for rectifying difficulties of problem solving where difficulties are relevant to the students logically (Roselainy, 2008; Zeynivand, 2015).

Since, most of the students' difficulties are related to problem solving, the reasons of these difficulties need to be determined for overcoming them in the learning of derivative and integral through mathematical thinking. This paper is based on a study of undergraduate students' errors in calculus, particularly their errors in performing derivative and integral. Hence, the main objective of this study is to identify the kinds of difficulties faced by students in the problem solving of derivative and integral and also the reasons behind these difficulties in the viewpoint of mathematical thinking.

\subsection{MATHEMATICAL THINKING}

Mathematical thinking is usually a dynamic process which requires highly complex activities, such as abstracting, specializing, conjecturing, generalizing, thinking, convincing, deducting, and inducting (Mason, Burton and Stacey, 1982; Tall, 1991; Yudariah and Roselainy, 2004). Examples of extensive studies on mathematical thinking are conducted by Mason, Burton and Stacey (1982), Dubinsky (1991), Schoenfeld (1992), Yudariah and Tall (1999), Dull and Tall (2001), Tall (2004). In developing mathematical teaching for classroom practice, researchers adopted the particular theoretical foundation of Tall (1995) and Gray et al. (1999) and used framework from Mason, Burton and Stacey (1982) and Watson and Mason (1998) (Yudariah and Roselainy, 2004; Roselainy, Yudariahand Builder, 2007; Roselainy, Sabariah and Yudariah, 2007; and Sabariah, Yudariah and Roselainy, 2008).

Tall (2004a, 2004b) believes that mathematical thinking involves three worlds namely; perceptional embodied, perceptual-symbolic and formal axiomatic which are important in the understanding of calculus especially derivative and integral concepts. Applications of mathematical thinking worlds are useful to enhance students' achievements in the learning of calculus, and can also be used in overcoming student' difficulties in calculus (Zeynivand, 2015; Khorasani, 2017). Moreover, Tall (1991) asserts that three worlds of mathematics can be used to solve problems based on mathematical thinking phases of Mason and his colleagues $(1982,2010)$.

Mason and his colleagues (2010) state that two phases; namely specialization and generalization should be followed in mathematical thinking process to solve problems. These phases involve three steps for solving problems namely; entry, attack and review. Specialization covers entry and attack, and generalization involves attack and review. However, conjecturing must be considered to transit from specialization phase to generalization in the attack step (Rosolainy, 2008; Mason et al., 2010).

Entry starts when a person encounters the problem or question for first time, and when he or she is involved in attempting in solving problem. Past experiences and reading questions carefully play important roles to answer basic questions in Entry phases such as; what I know, what I want and what I can introduce. Working in the Attack phase begins when everybody feels that the question has moved inside him and become his own. The phase is augmented when the problem is solved. Within Attack, several various approaches maybe formed and several plans may be designed and tested. When a new plan is being performed, work may promote at an enormous rate (Rosolainy, 2008; Mason et al, 2010).

Specialization as first operational process is important in solving problems, and it should be used systematically. Specialization in the teaching of mathematics and problem solving can be used in various cases or examples (Mason, Burton and Stacey, 2010). Specialization means referring to specific and particular examples in order to solve problems. The examples should be systematic instances of more general situations of a problem (Mason, Burton, Stacey, 2010). According to Mason, Burton and Stacey (2010), if specialization happens well, a useful conjecture can be helpful in inducting to achieve generalizations in any problem solving process.

Generalization is the main process of mathematical thinking in problem solving (Mason et al, 2010; Zeynivand, 2015). When a student faces new concepts or new problems, formulation is formed in his or her mind after specializing and conjecturing. It is the beginning point in utilizing generalization to solve problems based on mathematical thinking (Mason, Burton and Stacey, 2010). Generalization activity can be extended to previous knowledge or to new related concepts. Polya (1988), Karamzadeh (2000) and Mason et al., (2010) express that generalization as a main phase of mathematical thinking can be used to solve problems. Specifically Tall (1991) believes that it can be used to solve problems of derivative and integral.

The aims of the study were to know the kinds of difficulties faced by students in solving problems of derivative and integral, and the reasons behind these difficulties. Thus, the students' responses to the open ended questions were investigated to figure out their difficulties in conceptual understanding and problem solving of derivative and integral. Furthermore, the difficulties were judged based on mathematical thinking in conceptual understanding and problem solving.

\subsection{METHOD}

The study involved 63 students who were selected randomly from Islamic Azad university of Gachsaran who had taken calculus (I) at the first year of undergraduate level in Iran. The course of calculus (I) contained derivative and integral. To obtain the goals of this study, the selected students were given open ended problems of derivative and integral. Researchers tried to see if the students had difficulties in solving problems of these concepts, and to investigate the reasons for the difficulties.

This research engaged 9 problems (6 derivatives and 3 integrals) for problem solving. The problems were designed based on the framework of Mason and colleagues (2010). Besides, three experts who were familiar in this case verified the problems used in this research. The list of the problems is presented in Table 1. 
Table 1 Problems of derivative and integral

\begin{tabular}{|c|c|c|}
\hline Concept & No. & Content \\
\hline \multirow{6}{*}{ Derivative } & 1 & $\begin{array}{l}\text { Motion equation for a car is } \mathrm{X}=5 \mathrm{t}^{2}+4 \text {. i) Find the average velocity of this car from } \mathrm{t}=3 \text { to } \mathrm{t}=5 \text {. ii) } \\
\text { How can the average velocity be from } \mathrm{t}=\mathrm{k} \text { to } \mathrm{t}=\mathrm{n} \text { ? iii) Find the moment velocity in } \mathrm{t}=4 \text {. iv) How could } \\
\text { the moment velocity be found in } \mathrm{t}=\mathrm{k} \text { ? }\end{array}$ \\
\hline & 2 & Find the equation of tangent line for a curve as $\mathrm{f}(\mathrm{x})=\mathrm{x}^{\mathrm{n}}$ at the point of $\mathrm{A}=(1,1)$. \\
\hline & 3 & Let $f(x): R \rightarrow R, f(x)=|x|$, find $\lim _{x \rightarrow n} \frac{f(x)-f(n)}{x-n}$. \\
\hline & 4 & $\begin{array}{l}\text { After } t \text { minutes of starting to disembogue for a large water tank, the volume of water equal } v(t)= \\
250(16-t)^{2} \text {. Find the disembarkation rate after } \underline{n} \text { minutes. }\end{array}$ \\
\hline & 5 & Let $f(x)=x^{2}$. i) Calculate $\lim _{x \rightarrow 2} \frac{f(x)-f(2)}{x-2}$.ii) How can the solution be of $\lim _{h \rightarrow 0} \frac{f(2+h)-f(2)}{h}$ ? \\
\hline & 6 & if $f(x)=c x^{n}$, then find the answer of $\lim _{x \rightarrow 1} \frac{f(x)-f(1)}{x-1}$. \\
\hline \multirow{3}{*}{ Integral } & 7 & Question 1: If $\mathrm{g}^{\prime}(\mathrm{x})=\mathrm{a} \mathrm{x}^{\mathrm{n}}+\mathrm{bx}$, then how can be $\mathrm{g}(\mathrm{x})$ ? \\
\hline & 8 & $\begin{array}{l}\text { Find the area between the graph of function with the formula as } f(x)=x+1 \text { and } X-\text { axis from } x=k \text { to } \\
x=k+n \text {. }\end{array}$ \\
\hline & 9 & $(x)=x^{2}$ in $[0, n]$. \\
\hline
\end{tabular}

The problems of derivative and integral were given to the students. The score of each student was calculated for derivative and integral. The marks were scored from 20, since according to Iranian marking rate, scores should be from 0 to 20 . The researchers investigated the scores of problem solving separately for each concept. A few quantitative results descriptively indicated the mean of students' marks and rates of students who could solve the problems to see if they actually had difficulties or not. Students' responses to the questions were analyzed qualitatively to identify the reasons for having the possible difficulties.

\subsection{FINDINGS}

The findings of this study are presented in quantitative and qualitative results. These results are based on students' responses for both derivative and integral when they solved the problems.

\subsection{Quantitative Findings}

The students' marks of problem solving were calculated to determine their ability to solve problems of derivative and integral. The mean of students' scores for problem solving was 9.1(from 20) with std. deviation of 2.3. The quantitative results of students' responses to open ended problems of derivative and integral are shown in Table 2. The frequency of students who solved the problems and the percentage for students who solved every problem is presented in the table.

Table 2 Quantitative results of students' responses

\begin{tabular}{cccc}
\hline Concepts & Problems & Number of students' who gave correct answer & $\begin{array}{c}\text { Percenta } \\
\text { ge }\end{array}$ \\
\hline \multirow{3}{*}{ Derivative } & 1 & 6 & $9.5 \%$ \\
\cline { 2 - 4 } & 2 & 9 & $14.2 \%$ \\
\cline { 2 - 4 } & 3 & 11 & $17.4 \%$ \\
\cline { 2 - 4 } & 4 & 0 & $0 \%$ \\
\hline \multirow{2}{*}{ Integral } & 5 & 7 & $11.1 \%$ \\
\cline { 2 - 4 } & 7 & 4 & $6.3 \%$ \\
\cline { 2 - 4 } & 8 & 9 & $14.2 \%$ \\
\cline { 2 - 4 } & 9 & 8 & $12.6 \%$ \\
\hline
\end{tabular}

Referring to the above table, the frequency was based on the students who had given correct and complete answers to the problems. Therefore, the incorrect or incomplete ones were not included in the data.

The results of calculating students' marks indicated that students had difficulties in the learning of derivative and integral. The results of students' frequencies demonstrated that students could not answer open ended questions. Moreover, the percentages of students who gave correct and complete answers showed that majority of students were not able to answer the questions. The weakness of responding the questions was discovered for problem solving in derivative and integral. The qualitative data for this study is presented below. 


\subsection{Qualitative Findings}

This qualitative data demonstrate the roots and natures of difficulties experienced by the students based on mathematical thinking through the questions of derivative and integral which were given to the students. The descriptive results of students' responses to the problem solving questions were reported earlier in this investigation. Those results indicated poor success of solving problems in the learning of derivative and integral. Here, the researchers wanted to know the reasons behind this weakness.

\subsubsection{Problem Solving in Derivative}

In problem solving of derivative, 6 open ended questions were given to the students to answer. The content of each question and analysis of all 63 students' responses are presented in the following.

In solving the first problem, 18 students did not give any responses. 13 students solved only the first part of this question. They did not mention the application of derivative in solving this kind of problems, and they solved this part by using the formula of $\Delta V$ and $\Delta t$. Although, their responses to the first part of this problem were correct, they were not able to solve other parts of the problem. Only the first and second parts were solved by 5 students. They answered these parts completely without any attempting to solve other parts of the question. In addition, they wrote that there were no differences between moment velocity and average velocity.

Then, 10 students answered only the first and third parts of the question. They tried to answer the second and fourth parts, but they could not get the answer through problem solving. They did not know how they should attack the problem to solve it. Those students wanted to reach the answers for the second and fourth parts directly without any calculation. Moreover, they had difficulties in using their information in solving the higher level of problem. An example of the students' response is given in Figure 1.

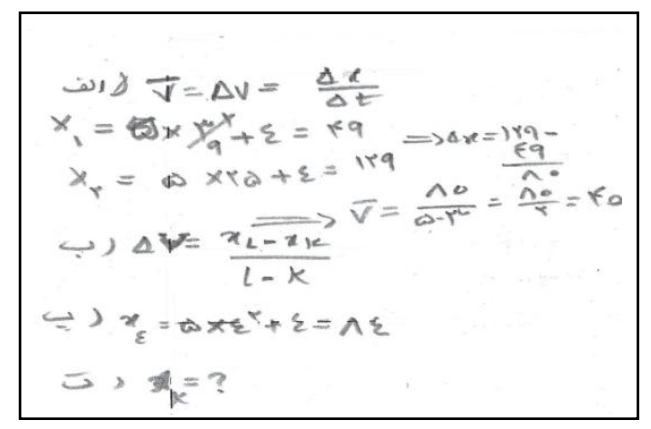

Figure 1 A student's attempt in solving the problem, but unsuccessful to find the general parts

11 students answered the first, second and third parts of the question. They did not mention the fourth part. Finally, 6 students from 63 answered all parts of the question. However, they did not utilize any logical problem solving plan through their solution method. Although their answers were correct, the answers were not perfect based on problem solving framework of Mason. They had difficulties to give some examples and conjecture the main idea of examples. Furthermore, they did not use generalization in their respon ses. Figure 2 shows an example of how students presented their solution.

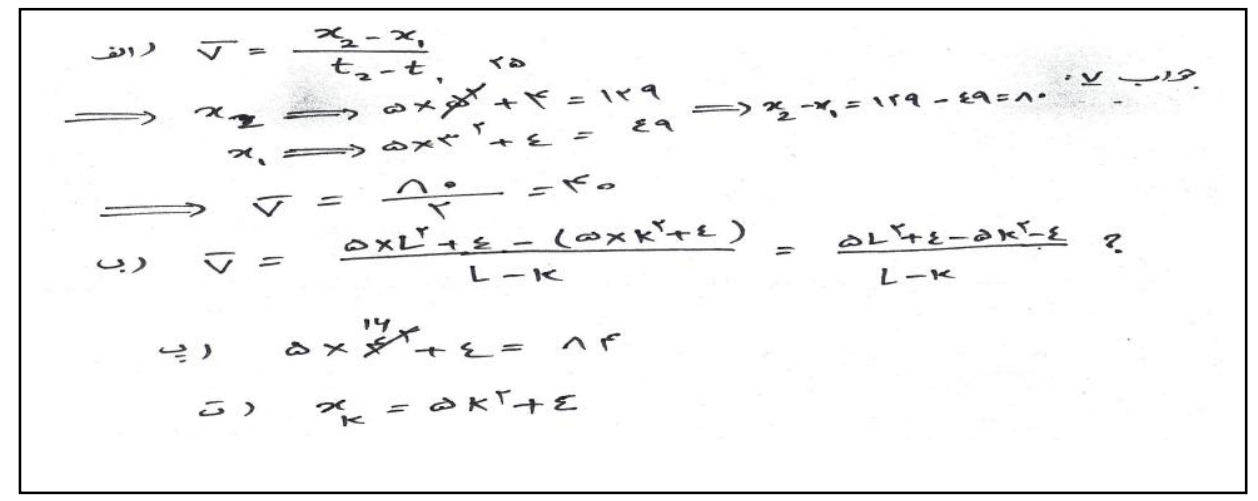

Figure 2 The weakness of following the problem solving process

According to Figure 2, students could not design a plan to solve the problem due to their inability to follow problem solving process successfully to reach the answers.

In addition, the second problem of derivation was ignored in the worksheets of 27 students. They did not answer the question. Six students only sketched the graph with tangent line for this question, but they did not find the equation. However, 2 students sketched a graph and mention the term of derivative, but they were not able to use the properties of derivative to find the equation. 
Twelve students wrote the formula of tangent line equation, but they could not change the formula based on given function and point. Although they wanted to solve this question by using familiar context, they could not complete it. Figure 3 (a) shows a sample of responses. Thirteen students gave complete answer to this question. They displayed acceptable solution and an illustration of their answers is presented in Figure 3(b).

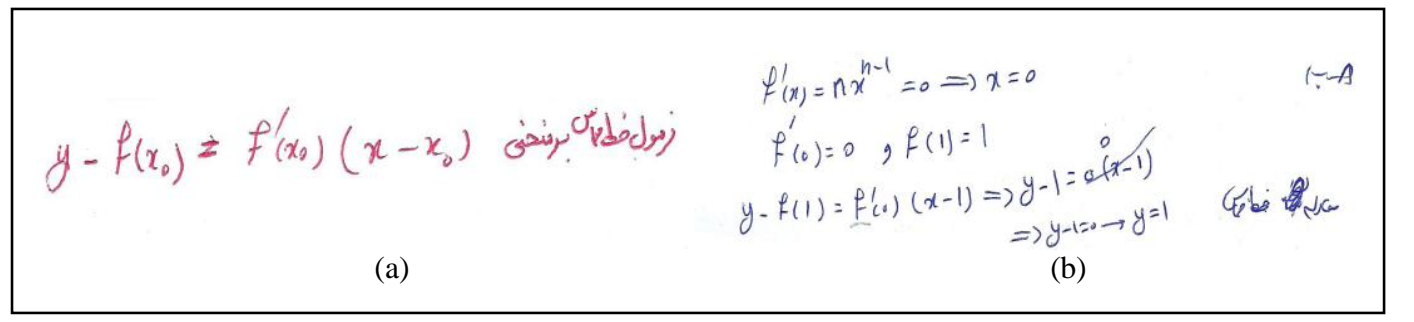

Figure 3 (a) Only the formula was given without connection to the given problem. (b) Showing algebraic solution only

Although 13 students mentioned in the previous paragraph solved the problem, none of them used graph. Nine students used graph and figure in solving this question in addition to giving complete algebraic answer. Their sketched graphs were general imagination of a graph, shown as common postures of graphs and curves in calculus books, because sketching the graph of $f(x)=x^{n}$ is impossible. Figure 4 shows an example of this solution.

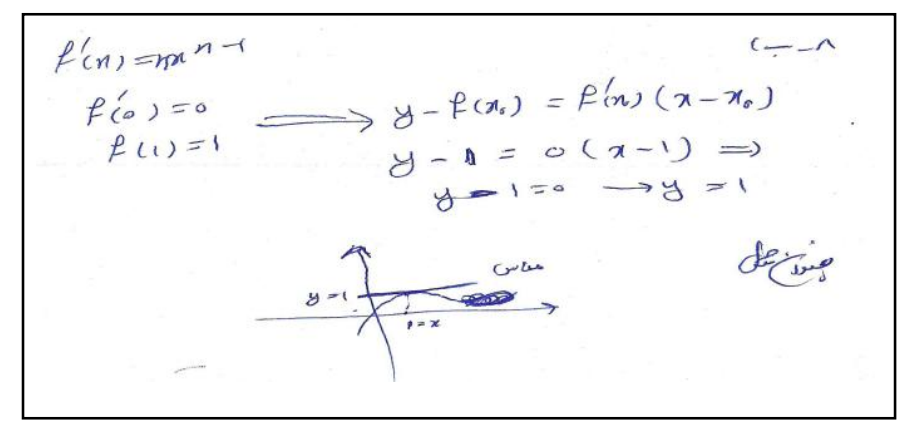

Figure 4 A response which contains algebraic solution and graphical posture

Nineteen students did not give any solution for the third problem of derivation. Nine students answered to the problem by writing only "the limit of function is undefined because of $0 / 0$ ", but they did not explain how they found indeterminate form $0 / 0$ or did not explain because makes denominator zero. Ten students gave answers such as "the limit of function does exist" or "the limit of function does not exist". A few of these 10 students also mentioned the right-hand limit and left-hand limit are not equal without finding them mathematically in the solution process.

Fourteen students used the properties of limit in solving this question, but they did not pay attention to the absolute function properties. They gave wrong answers, and they wrote that the function had limit in the given point. They could not use the exclusivities of absolute function in order to find limit in the given point. An example of this type of response is given in Figure 5 (a). In contrast, 11 students solved this question completely. They were able to consider the properties of absolute function in the calculation of its limitation in a point. The example is given in Figure 5 (b). However, no student used graphical aspect to show the posture of this question based on limitation notion.

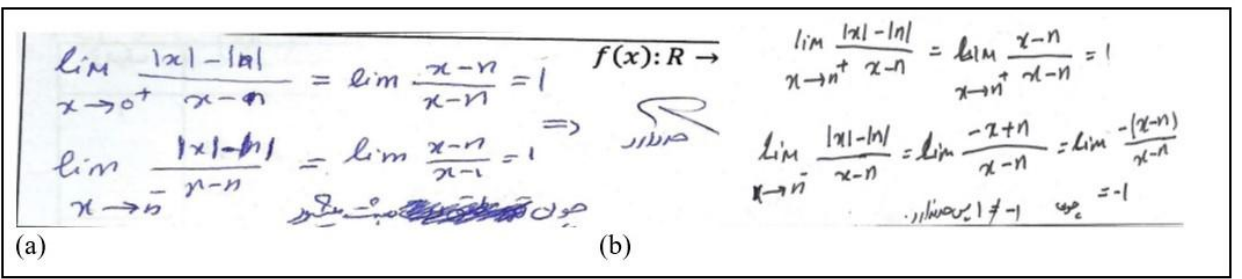

Figure 5 (a) Showing the wrong response because no consideration to properties of absolute function.

(a) Showing the correct answer without using any graphical posture

No student gave suitable response to the $4^{\text {th }}$ problem. Few students only drew a model of water tank. This answer implies that they could not use derivative to solve this sort of problem. Since this question is a type of optimization problems, it shows that there was a lack of generating derivative properties from the solving of optimization problems (Thomas, 2009). Apparently students were not informed with 
regards to application of derivative in the real world since this problem is an example of using derivative in the real world. Hence, they could not imagine the actual extending of concepts such as derivative in their daily lives. In other words, they could not use their prior knowledge in new situations.

Thirteen students did not answer to the fifth problem. However 16 students managed to answer the first part incompletely. They wrote that the answer of this part was ambiguous. Majority of them obtained the ambiguous by calculation of $\frac{x^{2}-4}{x-2}=\frac{0}{0}(x \rightarrow 2)$. Although they were taught the methods to disambiguate the functions in the limitation concept, they could not remember it.

With this problem, 18 students have solved only first part of it completely. Those students did respond to the second part of the question. They avoided a more general form of this question presented in the second part. Nine students responded the first part completely and gave a brief answer to the second part. They only concluded that the answer to the second part was ambiguous, but they did not try to disambiguate it to reach the correct answer. An illustration of this kind of answer is shown in Figure 6 (a). However, 7 students could answer the question completely and their answers were the best answers among all 63 students. This kind of solution is given in Figure 6 (b)

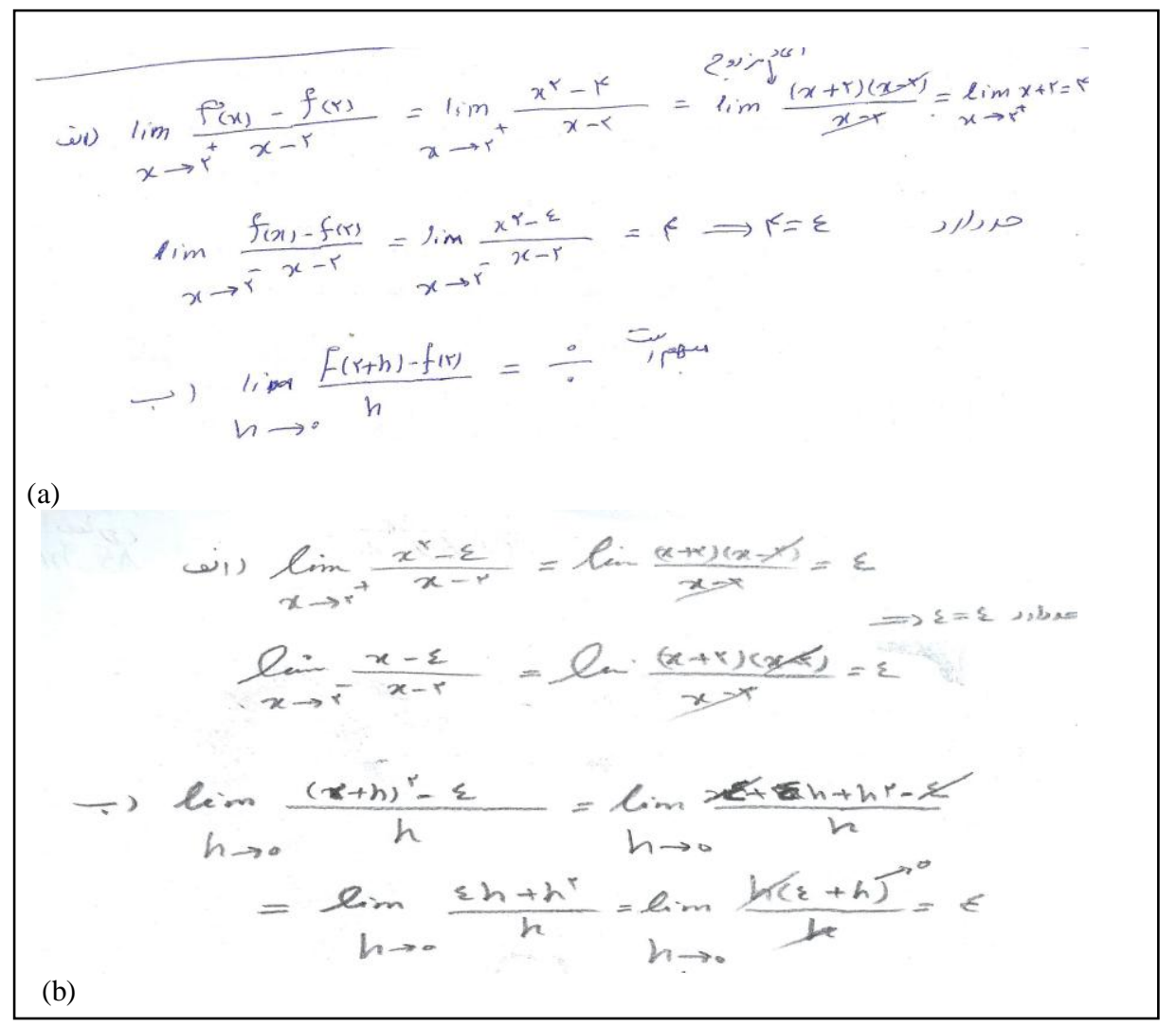

Figure 6 (a) Showing the right answer for the first part and the weakness of solving second part (b) Showing the correct responses to both parts algebraically

Although the sixth problem is about using function from $n$th degree and students should learn it in high school, the number of students who did not answer this question was incredible. Forty one students did not make an attempt to answer the question. Thus, there was a weakness of using properties of function from $n$th degree in solving more general problems among students. However, twelve students displayed their efforts to solve this problem. They were only able to replace the $f(x)$ in the limitation formula. The example is given in Figure 7 (a). Six students tried to find the answer, but they did not obtain the final answer. They were confused in the last part of their problem solving process. An example of this kind of answer is shown in Figure 7 (b).

Only 4 students could find the final answer for this problem. They responded to the problem correctly to obtain the right answer. They used their previous information about dealing with polynomials in solving this problem. Therefore, it is clear that it is important to use the prior knowledge in solving mathematical problems (Polya, 1988). Figure 7 (c) shows an example of those students' responds. 


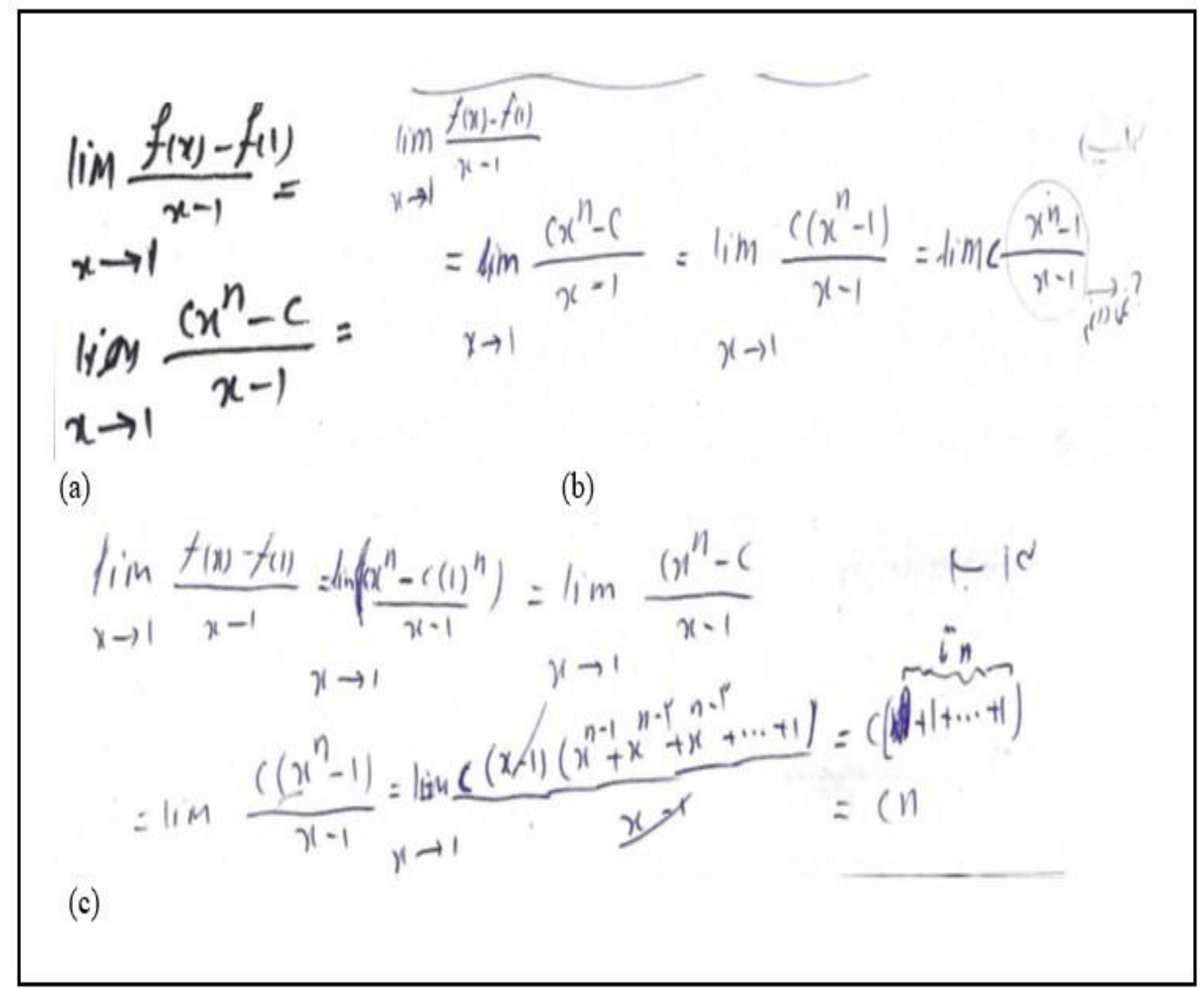

Figure 7 (a) Showing only formula was written.

(b) Showing weakness of using previous information in a new situation.

(c) Showing a complete answer without any embodied aspect

In the following sub-section, the students' responds in solving the problems of integral were analyzed qualitatively in order to see the posture of their answers.

\subsubsection{Problem Solving of Integral}

Students were given 3 questions which were designed with regards to problem solving for integral concept. The questions contained definite and also indefinite one variable integral concept. The ideas of Polya $(1982,1988)$ in addition to Mason et al. (2010) regarding problem solving were taken into consideration in designing these types of questions. The results of analysis indicated that the students' marks in the solving these questions were in a low level. The aim of doing qualitative analysis is to see which factors prevent students from solving these problems.

Eleven students did not answer the first problem of integral. Although 17 students attempted to solve this problem, they could not solve it completely. They focused on only one term of the function which was a polynomial function. It means that some students found the answer for the first term but gave up working on the second term. In contrast, some students worked on the second term without giving attention to the first. While 16 students endeavored to consider both terms of the function rightly, they forgot to write denominators for each term of answers. At least, there were some efforts to solve this problem based on their responses to the problem in the answer sheets.

Ten students provided the correct answers to this question. Their responds were the common method used by students to answer the problems. They found the answer for $a x^{n}$ and $b x$ separately and then joined answers to each other. Figure 8 (a) shows an instance of their answers. In addition to the 10 students, 9 students solved this problem correctly, but they used examples in the lower degrees of polynomials before doing this question. They tried to conclude their answers to the pair terms of this question by using general guess based on the specialization of written examples. A sample of this answer is presented in Figure 8 (b). 


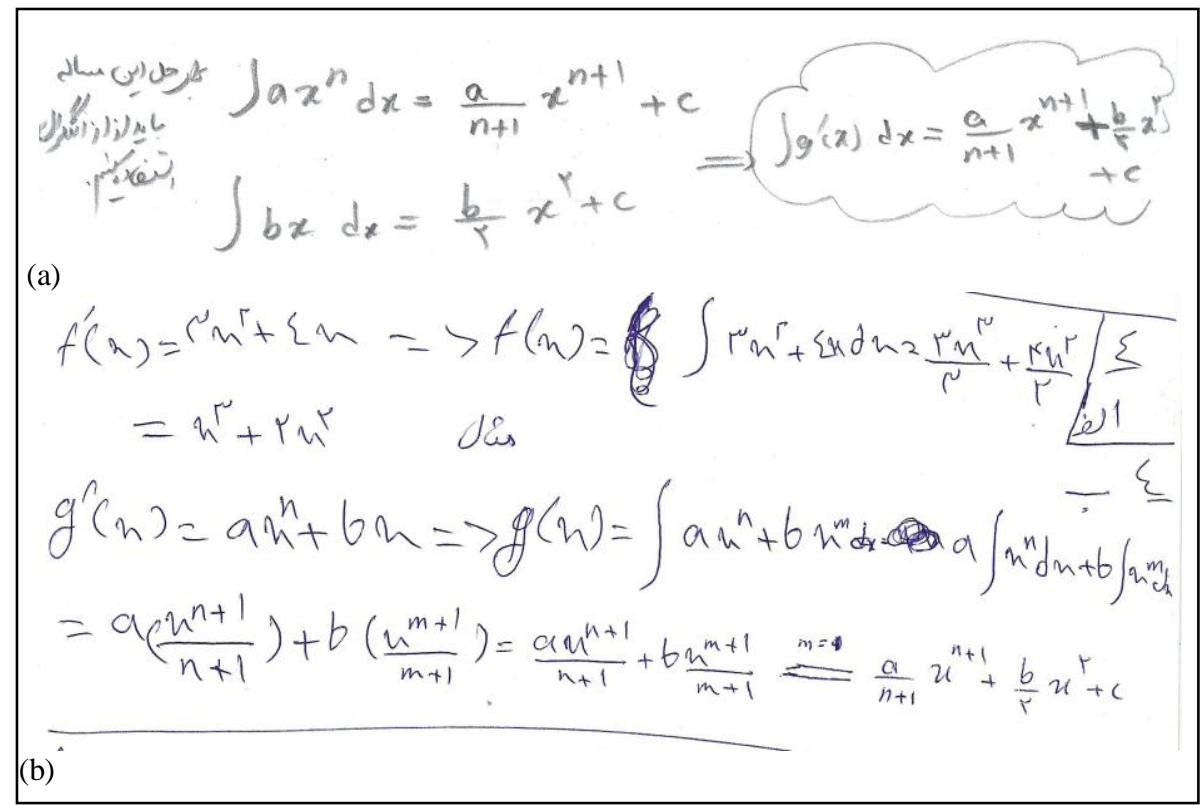

Figure 8 (a) Solving each term separately and joining them at the final step

(b) Using specialization in solving the problem where by specialization gives a direction to solve the main problem

In addition, 18 students wrote nothing to solve the second problem. However, 23 students were able to sketch the graph of function $f(x)=x+1$ without more efforts to solve the problem. 9 students tried to determine $x=k$ and $x=k+n$ on $x$-axis through sketching the graph of $f(x)=x+1$. Although they could sketch trapezoid correctly, they did not solve the problem.

Moreover, 5 students could solve the problem algebraically via using the integral. They did not apply shape or figure, but they determined the boundary of integral and found its real answer. In addition to using integral algebraically, 8 students used both geometrically and algebraically methods to solve this problem. It means that they finite integral to solve the problem. Furthermore, they showed the accuracy of their solutions by sketching the graph and figures for this problem. The example is shown in Figure 9.

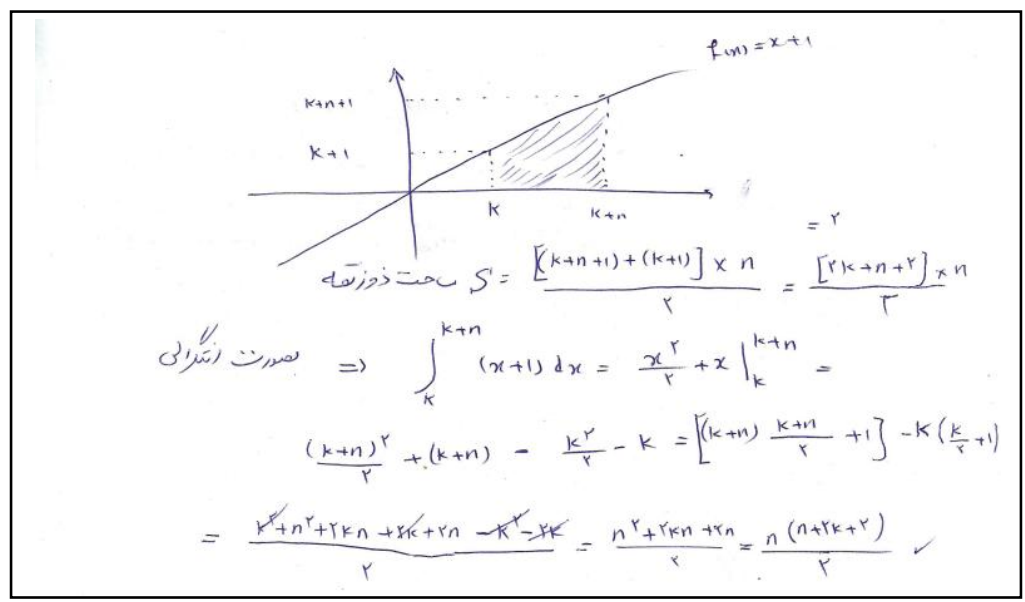

Figure 9 Showing the solution which contained algebraic and symbolic aspects

For the $3^{\text {th }}$ problem of integral, there was no remarkable answer among 63 learners. A few students just sketched the graph of function. Although students were familiar with the series and their applications from high school, they could not show how the upper and lower summation can be based on the sketched graph. When some students were asked on their inability to answer this problem, they asserted that they could not use the properties of series. They also added that it was difficult for them to make linkage between their information of series concept and the condition of this problem. 


\subsection{DISCUSSION}

Based on the responses to the questions of derivative and integral in the problem solving part, it seems that the students had difficulties to find the real answers for the questions. There were some reasons to prevent students to solve the derivative problems. There was a weakness of using earlier known information to solve the new problems among students. In many cases, students could not use the properties of polynomials, function, limit and utilizations of limit to solve the problems of derivative concept. Although some students tried to solve the problems, they got confused in the first step of problem solving process. They could not conduct their efforts to reach answers based on the problem solving steps. In other words, there was no coherence in the problem solving stages among those students for derivative concepts. A majority of students could not consider the problem solving processes; namely entry, attack and review. Most of them gave up whole or some parts of these steps in solving the problems. Similar scenario also existed when solving integral.

Some reasons for the students' difficulties are highlighted such asfirst, the weakness in applying prior knowledge to the new problems. For instance, most of the students could not use the properties of derivative to solve the first question. Similar weakness was also seen in the answering of the second question since they could not remember the formula of calculating the area of trapezoid. They had serious difficulty in Entry phase of mathematical thinking in Specialization step.

Furthermore, the students could not determine the method of problem solving process when solving integral problems. Apparently, they did not use any problem solving instruction such as using Polya's or Mason's framework. Besides, another factor which caused the difficulties was the weakness of working with general problems in the problem solving process. Most of the students used disjunctive generalization to solve the general problems. However, Haber and Tall (1991) and Tall (2002) asserted that using this kind of generalization creates some difficulties to students since students could not use specialization and conjecturing in Entry and Attack phases. They used a general rule or theorem in solving the problem without making any relationship with examples. This weakness was visible in the solving of both derivative and integral problems.

Therefore, the above results indicate that undergraduate students faced significant difficulties in the learning of derivative and integral. Three factors cause the difficulties. First, the inability to use suitable problem solving framework. Although there are some frameworks such as Polya (1988) and Mason et al. (2010), the students were not able to use any of them. Students need to have a plan from the beginning to the end in order to find the answer in the problem solving process for mentioned concepts as suggested by Khorasani (2017) and Tavanaei (2018).

Second, the weakness to use prior knowledge in order to solve new problems happened many times. For instance, when students face an integral problem, they cannot use the properties of function, limitation, applications of limitation, derivative and its utilization to solve this problem. It is necessary to adopt a strategy in overcoming this difficulty. Finally, students had difficulties when they are asked to solve problems in general forms. They could not give specific examples and relate them to the general forms. Hence, they need to work with these kinds of problems by using generalization strategy to solve the general problems of derivative and integral. It shows that students could not conjecture the general form, and they were not able to use generalization based on conjecturing within Attack phase.

The students used symbolic aspects of derivatives and integrals rather than graphical and embodied aspects. Also, making connection between embodied and symbolic aspects of the both concepts to draw the graphs and explaining geometrically has been done rarely by the students.

\subsection{CONCLUSION}

Based on the findings of this study, students have difficulties in the learning of derivative and integral. The results of quantitative analysis indicated that the marks of students were evidence of poor achievement in the problem solving of derivative and integral. The qualitative analysis remarked some reasons for these difficulties based on mathematical thinking. The students focused more in the symbolic world rather than embodied world. Besides, there is also the weakness in making connection between embodied and symbolic worlds of the concepts to sketch the graphs and geometrical interpretation. In addition, there is also the lack of using problem solving framework and weakness of recalling previous knowledge in new situation to make specialization and conjecturing to reach generalization. Finally, there is a weakness in using general imagination in solving the problems of derivative and integral. Apparently, students prefer to solve specific problems rather than general problems. Therefore, there is a need to find suitable mathematical thinking strategy to overcome these difficulties in order to improve students' problem solving abilities in the learning of derivative and integral. The results of this analysis will help future researchers to select and design effectiveness learning techniques to overcome the mentioned difficulties based on mathematical thinking approach.

\section{References}

Aghaee, M. (2007). Investigation of Controlling Abilities for Solving Problem in Infinite Integral. Unpublished Master Thesis. Shahid Bahonar University, Iran.

Azarang, Y. (2008). Learning of Calculus With Concepts of Limit and Symbolic. Iranian Mathematics Education Journal, 27(1), 4-10.

Azarang, Y. (2012). Quality of Leaning Calculus in Iran. Roshd Mathematics Education Journal, 27(1): 24- 30.

Cline, K., Parker, M., Zullo, H., Stewart, A. (2012). Addressing Common Student Errors With Classroom Voting in Multivariable Calculus. PRIMUS, 23(1), 60-75

Dubinsky, E. (1991). Reflective Abstraction in Advanced Mathematical Thinking. In D. O. Tall (Ed.), Advanced Mathematical Thinking, 95-123. Dordrecht: Kluwer Academic Publishers.

Ghanbari, G. (2010). Looking to Change of Calculus in Iran. Mathematics Education Journal, 27(1), 59- 61.

Ghanbari, G. (2012). Drwing Figures as a Problem Solving Method. Roshd Mathematics Education Journal, 27(1), 38 - 41.

Gray, E.and Tall, D. O. (2001). Relationships Between Embodied Objects and Symbolic Procepts: An Explanatory Theory of Success and Failure in

Mathematics. Proceedings of the 25th Conference of the International Group for the Psychology of Mathematics Education, Utrecht, The Netherlands, 3 , $65-72$. 
Haber, S.and Abboud, M. (2006). Students' Conceptual Understanding of a Function and Its Derivative in an Experimental Calculus Course. Journal of Mathematical Behavior, 25, 57-72.

Hirst, K. (2002). Classifying Students' Mistakes in Calculus. In Proceedings of the 2nd International Conference on the Teaching of Mathematics (at the undergraduate level).

Javadi, M. (2008). Perception of Concepts and Definition of Concept for Calculus. Roshd Mathematics Education Journal, 27(2), $23-27$.

Kashefi, H. (2012). Mathematical Thinking in Multivariable Calculus Through Blended Learning. Unpublished Ph.D Thesis. Universiti Teknologi Malaysia (UTM). Malaysia

Kiat, S. E. (2005). Analysis of Students’ Difficulties in Solving Integration Problems. The Mathematics Educator, 9(1), 39-59.

Kirkley, J. (2003). Principles for teaching problem solving. PLATO Learning Inc.USA.

Khorasani, A. (2017). Using Game Theory in Teaching High School Mathematics based on Mathematical Thinking. Unpublished Master Thesis. University of IAU Behbahan. Iran

Mason, J. (2002). Generalisation and Algebra: Exploiting Children's Powers. In L. Haggerty (Ed.) Aspects of Teaching Secondary Mathematics: Perspectives On Practice. London: RoutledgeFalmer, 105-120.

Mason, J. (2010). Attention and Intention in Learning About Teaching Through Teaching. In R. Leikin and R. Zazkis (Eds.) Learning Through Teaching Mathematics: Development of Teachers' Knowledge and Expertise In Practice, 23-47. Springer, New York.

Mason, J. (2012). A Phenomenal Approach to Mathematics. Retrieved on March, 2013 from http://www.xtec.cat/centres/a8005072/articles/phenomenal_approach.pdf.

Mason, J., Stacey, K.and Burton, L. (2010).Thinking Mathematically (2th edition), Edinburgh: Pearson.

Metaxas, N. (2007). Difficulties on Understanding the Indefinite Integral. In Woo, J. H., Lew, H. C., Park, K. S., Seo, D. Y. (Eds.). Proceedings of the 31 st Conference of the International Group for the Psychology of Mathematics Education, 3, 265-272. Seoul: PME.

National Assessment of Educational Progress (NAEP). (2003). What Does the NAEP Mathematics Assessment Measure? Retrieved on March, 2013 in http//:www.nces.ed.gov/nationsreportcard/mathematics/abilities.asp.

Orton, A. (1983a). Students' Understanding of Integration. Educational Studies in Mathematics, 14, 1-18.

Orton. A. (1983b).Students' Understanding of Differentiation. Educational Studies in Mathematics, 14, 235-250.

Parhizgar, B. (2008). Conceptual Understanding of Function. Unpublished Master Thesis. University of Shahid Beheshti. Iran.

Pepper, R., E. Stephanie V. Chasteen, Steven J. Pollock and Katherine K. Perkins. (2012). Observations on Student Difficulties with Mathematics in Upper-Division Electricity and Magnetism. Physical Review Special Topics- Physics Education Research. 8(010111): 1- 15.

Polya, G. (1982). Mathematical Discovery: on Understanding, Learning and Teaching Problem Solving (Combined Ed.). New York, NY: Wiley.

Polya, G. (1988). How to Solve It. USA: Princeton University Press.

Roknabadi, H. A. (2007). Varieties of Conceptual Understanding: Different Theories. Unpublished Master Thesis. Shahid Bahonar University, Iran.

Roselainy Abdolhamid. (2008). Changing My Own and My Students'Attitudes to Calculus Through Working on Mathematical Thinking. Unpublished Ph. D. Thesis. Open University. UK.

Rubio, B. S.and Chacón, Gómez-I.M. (2011).Challenges with Visualization. The Concept of Integral with Undergraduate Students. Proceeding the Seventh Congress of European Society for Research in Mathematics Education (CERME-7). $9^{\text {th }}$ and $13^{\text {th }}$ Feb, University of Rezeszow, Poland.

Schoenfeld, A. H. (1992). Learning to Think Mathematically: Problem Solving, Metacognition, and Sense-making Mathematics. Grouws, D. (Ed). Research on Mathematics Teaching and Learning: 334-370. Macmillan, New York. USA.

Shahshahani, S. (2012). Why Calculus in Iran? Retrieved from: http://matheducation.blogfa.com/post-6.aspx.

Stacey, K. (2006). What Is Mathematical Thinking and Why Is It Important? University of Melbourne, Australia.

Tall, D. (1986).Building and Testing a Cognitive Approach to the Calculus Using Interactive Computer Graphics, Ph.D Thesis, the University of Warwick.

Tall, D. (1992). Conceptual Foundations of the Calculus. Proceedings of the Fourth International Conference on College Mathematics Teaching, $73-88$.

Tall, D. (1993). Students' Difficulties in Calculus. Proceedings of Working Group 3 on Students' Difficulties in Calculus,ICME-7, Québec, Canada, 13-28.

Tall, D. (1995).Mathematical Growth in Elementary and Advanced Mathematical Thinking, (Plenary Address). In Luciano Meiraand DavidCarraher (Eds.), Proceedings of PME 19(1): 61-75. Recife, Brazil.

Tall, D. (1997). Functions and Calculus. Retrieved from: http//: http://www.davidtall.com/.

Tall, D. (2001). Cognitive Development in Advanced Mathematics Using Technology, Mathematics Education Research Journal, 12 (3), $196-218$.

Tall, D. (2002a). Advanced Mathematical Thinking (11 Ed.). London: Kluwer academic publisher.

Tall, D. O. (2002b). Differing Modes of Proof and Belief in Mathematics, International Conference on Mathematics: Understanding Proving and Proving to Understand, 91-107. National Taiwan Normal University, Taipei, Taiwan.

Tall, D. (2004a). Introducing Three Worlds of Mathematics. For the Learning of Mathematics, 23 (3), 29-33.

Tall, D. (2004b).Thinking through three worlds of mathematics. In Proceedings of the 28th Conference of the International Group for the Psychology of Mathematics Education (4: 281-288). Bergen: Bergen University College, Norway.

Tall, D. (2007).Developing a theory of mathematical growth. ZDM, 39(1-2), 145-154

Tall, D. (2008).The Transition to Formal Thinking in Mathematics. Mathematics Education Research Journal, $20(2), 5-24$.

Tall, D. (2010a). Perceptions, Operations and Proof in Undergraduate Mathematics, CULMS Newsletter (Community for Undergraduate Learning in the Mathematical Sciences). University of Auckland, New Zealand, 2, November 2010: 21-28.

Tall, D. (2010b). A Sensible Approach to the Calculus. (Plenary at The National and International Meeting on the Teaching of Calculus. 23-25th September 2010, Puebla, Mexico).

Tall, D. (2011). Looking for the Bigger Picture. For the Learning of Mathematics. 31 (2), 17-18.

Tall, D. (2012). Making Sense of Mathematical Reasoning and Proof. Plenary at Mathematics and Mathematics Education: Searching for Common Ground: A Symposium in Honor of Ted Eisenberg. April 29-May 3, 2012, Ben-Gurion University of the Negev, Beer Sheva, Israel

Tall, D.and Mohammad Yusof, Y. (2009). Changing Attitudes to University Mathematics Through Problem Solving. Educational Studies in Mathematics.Colección Digital Eudoxus, 1(3)

Tarmizi, R., A. (2010). Visualizing Students' Difficulties in Learning Calculus. Procedia Social and Behavioral Science, $8,377-383$.

Tavanaei, N. (2018). Using Mathematical Thinking in Teaching and Learning Geometry. 2th Conference of mathematices and Application, 2018, Behbahan, Iran.

Villiers, M. D.and Garner, M. (2008). Problem Solving and Proving via Generalization, Journal of Learning and Teaching Mathematics, 5, 19-25.

Watson, A.and Mason, J. (1998).Questions and Prompts for Mathematical Thinking. ATM, Derby.

Willcox, K. and Bounova, G. (2004). Mathematics in Engineering: Identifying, Enhancing and Linking the Implicit Mathematics Curriculum. In Proceedings of the 2004 American Society for Engineering Education Annual Conference and Exposition. USA.

Yazdanfar, M. (2006). Investigation of Studying Skills in Calculus for Undergraduate. Unpublished Master Thesis. Shahid Bahonar University. Iran.

Yee, N. K., Lam, T. T. (2008). Pre-University Students' Errors in Integration of Rational Functions and Implications for Classroom Teaching. Journal of Science and Mathematics Education in Southeast Asia, 31(2), 100-116.

Yudariah Mohamad Yusof. (1995). Thinking Mathematically: A Framework for Developing Positive Attitudes Amongst Undergraduates. Unpublished Ph.D. thesis. University of Warwick. UK

YudariahMohd. Yusof.and Tall, D. (1999). Changing Attitudes to University Mathematics through Problem-solving.Educational Studies in Mathematics, 37, 67-82.

Zeynivand, F. (2015). Mathematical Thinking in Learning Differential Equations through Computer Algebra System. Unpublished Ph.D Thesis. Universiti Teknologi Malaysia (UTM). Malaysia. 